\title{
Kepeloporan kewirausahaan memandu pendakian daya tarik wisata Gunung Agung, Karangasem, Bali
}

\author{
I Gede Mudana, I Ketut Sutama, Cokorda Istri Sri Widhari \\ Politeknik Negeri Bali \\ Email: gedemudana@pnb.ac.id
}

\begin{abstract}
Erupted in 1963, Mount Agung in Selat District, Karangasem Regency, the highest mountain in Bali, was started to be mounted by trekking/climbing tourists in 1980s. Since 1990 's especially 2000s, some initiatives to serve the trekking/climbing the volcanic mountain have emerged in the surrounding villages' people. The present study is done using a technic of qualitative data analysis. The result of study shows that Mount Agung is regarded interesting to climb not only because she has exotic beauty and challenges regarding the degree of difficulty (and the degree of danger the trekkers/climbers may face) to climb but also get some certain mythologies from her status as a sacred mountain believed by Balinese people, especially the Hindu followers. The entrepreneurship practices of the local society in Selat Village then come up not only to serve the trekking/climbing as usual but also to conserve the mountain environment and of course to keep the trekkers'/climbers' safety since the mountain has some taboos and restrictions in relation with the trekking/climbing itself.
\end{abstract}

Keywords: Mount Agung, entrepreneurship, tourism, trekking/climbing guide.

\begin{abstract}
Abstrak
Mengalami letusan besarnya yang terakhir tahun 1963, Gunung Agung di Kecamatan Selat, Kabupaten Karangasem yang merupakan gunung tertinggi di Bali mulai dikunjungi wisatawan pendaki sejak 1980-an. Sejak 1990-an terutama 2000-an, muncul inisiatif sejumlah anggota masyarakat di sekitarnya untuk melayani para wisatawan pendaki menjelajahi gunung berapi tersebut. Studi ini menggunakan teknik analisis data kualitatif. Hasil studi menunjukkan bahwa Gunung Agung dianggap menarik oleh para
\end{abstract}


wisatawan pendaki bukan saja karena keindahan eksotik dan tantangan tingkat kesulitan (serta tingkat kebahayaan) untuk menaklukannya, tetapi juga karena gunung ini menyimpan mitos-mitos tertentu dari statusnya sebagai gunung yang disucikan oleh masyarakat Bali pemeluk Hindu. Praktik-praktik kewirausahaan masyarakat Desa Selat pun muncul tidak saja untuk melayani pendakian sebagaimana umumnya melainkan sekaligus menjaga kelestarian lingkungan dan keselamatan wisatawan pendaki dengan banyaknya pantangan-pantangan yang ada terkait pendakian.

Kata kunci: Gunung Agung, kewirausahaan, pariwisata, pemandu pendakian.

\section{Pendahuluan}

Draktik pariwisata dengan latar alam pegunungan berupa 1 wisata mendaki (mountain tourism/climbing tourism) semakin menjadi daya tarik di banyak daerah tujuan wisata di dunia. Hal ini karena, bagi banyak wisatawan, pariwisata massa yang bersifat modern/konvensional dianggap tidak lagi memberi tantangan dan kepuasan yang berarti. Dalam banyak aspek, wisata mendaki atau wisata gunung memberikan harapan bagi industrialisasi pariwisata dalam rangka mewujudkan kesejahteraan masyarakat dengan membagikan secara adil kebermanfaatan dari pengeluaran wisatawan (tourist expenditure) hingga pelosok pedesaan. Pariwisata berbasis desa sudah nyata adanya di Bali, seperti Ubud di Kabupaten Gianyar yang sedemikian populer (Sanjaya, et al, 2017) atau Jasri di Kabupaten Karangasem yang mulai merangkak (naik) (Amerta, et $a l, 2017)$.

Gunung Agung termasuk gunung vulkanik (berapi), masih aktif, dan dalam sejarahnya telah beberapakalimeletus. Pascaletusan terakhir (1963) yang begitu membekas dalam memori masyarakat Bali karena banyak menimbulkan korban, tidak sedikit petualang dan/atau wisatawan mendakinya. Dari data yang diperoleh di lapangan, mulai 12 Februari 2017 sampai 03 Agustus 2017 ada 4.459 wisatawan pendaki Gunung Agung yang mendaki melalui Desa Selat untuk kemudian Dusun Sogra (Pura Pasar Agung) di Desa Sebudi dan memulai pendakian, di mana kebanyakan adalah 
wisatawan mancanegara. Angka tersebut menunjukkan rata-rata 630 orang per bulannya atau kira-kira 20 orang per harinya.

Pada awalnya, mereka yang mendaki gunung yang relatif sulit didaki ini umumnya tidak menggunakan pemandu, sehingga di antara mereka ada yang hilang, tersesat, mengalami kecelakaan, dan bahkan meninggal. Sejak tahun 1990-an, ketika jumlah wisatawan pendaki internasional dan domestik terus bertambah seiring semakin berkembangnya industrialisasi pariwisata Bali, mulai ada kesadaran di kalangan anggota masyarakat di Desa Selat, yang berinisiatif menyediakan jasa memandu pendakian Gunung Agung, dengan memasang papan-papan bertuliskan Mt. Agung volcano trek di pinggir jalan depan rumah pemandu. Pendakian ini terasa sangat menarik karena di sekitar gunung terdapat sejumlah daya tarik lainnya, katakanlah Pura Besakih yang merupakan pura terbesar di Bali dan bahkan "pusat kesucian" daerah ini. Belum lagi Pura Pasar Agung di lerengnya dan wisata rafting di Desa Rendang yang semakin populer.

Artikel ini membahas daya tarik yang menjadi magnet bagi kedatangan wisatawan untuk mendaki Gunung Agung dan aspekaspek kepeloporan kewirausahaan memandu pendakian yang dijalankan masyarakat Desa Selat. Secara umum studi ini dalam beberapa hal merupakan cara pengembangan iptek sosial-budaya bidang kepariwisataan yang tumbuh di tengah-tengah masyarakat, sehingga diharapkan memiliki dampak ekonomi kepada para pelaku kewirausahaan memandu wisata mendaki gunung, dalam hal ini Gunung Agung, di Desa Selat.

Tujuan penulisan ini adalah mengetahui daya tarik wisata Gunung Agung di samping secara agak pragmatis untuk ikut melakukan pengembangan kewirausahaan (entrepreneurship) bidang pariwisata pendakian gunung di wilayah pedesaan yang dengan sendirinya melahirkan sumber daya manusia (SDM) kewirausahaan masyarakat setempat yang cerdas, tangguh, dan berhasil dalam merespons besarnya minat pasar/wisatawan domestik dan mancanegara untuk menikmati keindahan dan eksotisme pegunungan. Tentu saja pengembangan kewirausahaan yang dimaksud relevan dengan cita-cita pelestarian alam dan upaya menjaga kesucian/kesakralan alam karena Gunung Agung oleh masyarakat Bali dianggap gunung yang suci. 
Para informan mencakup para pemandu (guides) pendakian yang memprakarsasi, sekaligus pelopor, dalam kewirausahaan tersebut. Mereka merupakan pemandu paling berpengalaman dalam memberikan pelayanan pendakian Gunung Agung, khususnya melalui jalur Desa Selat/Pura Pasar Agung. Dari sisi kepenelitian, aspek pengalaman informan harus diperhatikan. Sudikan (2001) memaparkan, tiga aspek mendasar pengalaman manusia yang diperhatikan, yaitu apa yang mereka lakukan, ketahui, dan benda-benda apa saja yang mereka buat dan gunakan dalam beraktivitas. Data yang diperoleh dianalisis dengan teknik analisis kualitatif, yakni dengan reduksi data, penyajian data, dan penyimpulan, sebagaimana dianjurkan Miles dan Huberman (1992: 15-19).

\section{Wisata mendaki gunung, pariwisata berbasis masyarakat, dan kewirausahaan}

Salah satu tujuan utama aktivitas bisnis kepariwisataan, apa pun bentuknya, adalah untuk meningkatkan taraf hidup dan kesejahteraan masyarakat. Karenanya, kewirausahaan menjadi krusial ketika geliat pariwisata dan jumlah kunjungan wisatawan di daerah tujuan wisata menunjukkan perkembangan positif. Praktikpraktik kewirausahaan dalam pariwisata dimaksudkan untuk mengurangi atau meminimalkan kemiskinan dalam masyarakat, lebih-lebih masyarakat pedesaan (rural community). Mengurangi kemiskinan juga menjadi poin terpenting dalam pengembangan kewirausahaan wisata alternatif dan wisata pedesaan (rural tourism) seperti dalam wisata mendaki dan wisata gunung Gunung Agung di Desa Selat, Kabupaten Karangasem.

Zhao dan Ritchie (2007) menyatakan peniadaan kemiskinan telah dijadikan prioritas utama oleh United Nations World Tourism Organisation (UNWTO), sebagaimana dibuktikan dengan dikeluarkannya konsep ST-EP (Sustainable Tourism as an effective tool for Eliminating Poverty). Sebaliknya, implikasi-implikasi dari pariwisata untuk peniadaan kemiskinan hampir semuanya diabaikan oleh komunitas akademis pariwisata. Riset yang relevan tampak terfragmentasi, cakupannya terbatas, dan kurang konsisten dalam hal pengembangan metodologis. Kajian Zhao dan Ritchie (2007) ini akan menjadi basis gagasan pengembangan pariwisata 
berparadigma pro poor tourism (pariwisata yang membela kaum lemah) dalam tulisan penulis di wilayah pedesaan di Desa Selat. Sebagaimana secara umum dipahami bahwa kaum lemah/miskin Indonesia kebanyakan berada di pedesaan.

Agar pembangunan pariwisata dapat berkelanjutan dan efektif, lebih-lebih dalam masyarakat pedesaan, pandangan dan harapan masyarakat setempat perlu dipertimbangkan. Itulah sebabnya, pengembangan pariwisata berbasis masyarakat (community-based tourism) dikembangkan dengan memerhatikan kepentingan berbagai stakeholder, yaitu pemerintah, swasta, dan masyarakat. Perlas (2000) mengistilahkan ketiganya sebagai tiga pilar (threefolding) politik-ekonomi-budaya. Dalam pengembangan pariwisata berbasis masyarakat, peran masyarakat dibuat lebih eksis, sehingga mereka pada akhirnya memeroleh bagian yang lebih baik dan nyata dibandingkan dalam pariwisata massa/ modern/konvensional. Menurut Dengnoy (2003), pengembangan pariwisata berbasis masyarakat dilaksanakan berdasarkan prinsip keseimbangan dan keselarasan antara kepentingan berbagai stakeholder pembangunan pariwisata. Karenanya, pengembangan pariwisata berbasis masyarakat menuntut koordinasi dan kerja sama serta peran yang berimbang antara berbagai unsur stakeholder termasuk pemerintah, swasta dan masyarakat (Nugroho dan Aliyah, 2013; Putra 2015). Gagasan Dengnoy (2003) ini sejalan dengan pandangan Tolkach dan King (2015), bahwa keberhasilan jaringan community-based tourism (CBT) tergantung pada badan pendanaan berwenang dan pada komunikasi antara para manajer dan pemangku kepentingan (stakeholder) dalam memertahankan keseimbangan kekuasaan.

Pariwisata berbasis komunitas tidak akan bermakna apa pun bagi masyarakat pedesaan yang bersangkutan tanpa tumbuhnya kewirausahaan setempat (localentrepreneurship). Bila kewirausahaan tersebut tidak ada, kegiatan bisnis pariwisata akan sama saja dengan tempat-tempat lainnya atau, dengan kata lain, "berbasis komunitas" hanyalah diksi dan jargon-jargon yang indah untuk diwacanakan. Dalam situasi seperti itu, pariwisata kembali akan bersifat kapitalistik, yakni dikuasai pemodal-pemodal besar.

Bagi Hisrich dan Peters (1995), kewirausahaan merupakan 
"the process of creating something different with value by devoting the necessary time and effort, assuming the accompanying financial, psychological, and social risks and receiving the resulting rewards of monetary and personal satisfaction".

Dengan cara yang berbeda, Siagian (1995) menyatakan,

"kewirausahaan adalah semangat, pelaku, dan kemampuan untuk memberikan tanggapan yang positif terhadap peluang memeroleh keuntungan diri sendiri dan/atau pelayanan yang lebih baik pada pelanggan/masyarakat, dengan selalu berusaha mencari dan melayani lebih banyak dan lebih baik, serta menciptakan dan menyediakan produk yang lebih bermanfaat dan menerapkan cara kerja yang lebih efisien, melalui keberanian mengambil risiko, kreativitas, dan inovasi serta kemampuan manajemen".

Karena praktik kewirausahaan pada dasarnya adalah diskursus kemasyarakatan, teori praktik dari sosiolog Pierre Bourdieu dari karyanya seperti The Logic of Practice (1990) penting dikemukakan. Bourdieu menekankan keterlibatan subjek (masyarakat pelaku) dalam proses konstruksi budaya yang bertalian erat dengan habitus, modal (capital), dan ranah (field). Teori ini merupakan produk dari relasi antara habitus sebagai pemahaman persepsi, modal sebagai kekuatan pendukung arena aktivitas kegiatan, dan ranah sebagai medan sosial.

\section{Gunung Agung sebagai daya tarik wisata}

Gunung Agung dalam sejarahnya telah beberapa kali meletus. Sampai kini ia masih tergolong aktif yang menunjukkan bahwa masih ada potensi untuk kembali meletus di kemudian hari sebagaimana gunung-gunung api lainnya yang masih aktif. Tidak mengherankan, pada saat ini (Oktober 2017), potensi semakin nyata dengan meningkatnya status ke dalam Waspada (sejak 13 September 2017), Siaga (sejak 18 September 2017), dan terakhir "Awas" (sejak 22 September 2017). Bahkan sampai kini ratusan ribu warga dari desa-desa terdekat gunung mengungsi ke luar Kecamatan Selat dan bahkan ke luar Kabupaten Karangasem.

Gunung Agung secara ilmu pengetahuan ilmiah boleh saja dianggap gunung (berapi) biasa sebagaimana gunung-gunung 
(berapi) yang lainnya baik di Indonesia maupun dunia. Meskipun demikian, dalam konteks sosial-budaya masyarakat Bali, penjelasan tentang Gunung Agung bisa beragam. Meskipun demikian, tidak berarti bahwa Gunung Agung merupakan satu-satunya gunung yang dianggap suci.

Gunung menempati posisi dan peran penting dalam berbagai agama. Ada agama-agama yang percaya bahwa gunung adalah tempat disampaikan atau diungkapkannya ajaran agama, atau tempat turunnya guru atau pendiri agama mereka dari sorga. Agama-agama lain menganggap gunung sebagai simbol pendakian spiritual. Oleh karena itu para penganut agama menjadikan gunung sebagai tempat suci dan sebagai tujuan dharma yatra (ziarah). Gunung Kaliasa (Kailash) di India dipandang sebagai tempat suci oleh empat agama, yaitu Hindu, Buddha, Jain, dan Bon. DiIndonesia, dikenal juga beberapa gunung yang dianggap sebagai tempat suci, seperti Gunung Agung, Gunung Batur, Gunung Batukaru, Gunung Semeru, Gunung Lawu, Gunung Merapi, dan Gunung Salak. Status sebagai tempat suci membuat gunung terlindungi dan terpelihara dari perusakan dan pencemaran. Oleh karena itu, gunung suci juga terjamin sebagai sumber air yang sangat penting bagi pertanian khususnya dan kehidupan umumnya (Media Hindu, Edisi 159, Mei 2017, hal. 1).

Dari cerita sejumlah penduduk berusia tua di Desa Selat, Gunung Agung dipercaya sebagai pecahan Gunung Semeru (di Pulau Jawa). Menurut legenda yang berkembang, dahulu Bali begitu sering diguncang bencana berupa gempa. Untuk mengatasinya, Dewa mengambil sebagian dari Gunung Semeru untuk dipindahkan ke Bali. Maksudnya adalah, pecahan tersebut diharapkan bisa membuat keseimbangan, sehingga Bali tidak lagi diguncang gempa. Secara legenda, Gunung Agung dan Gunung Semeru berhubungan satu sama lain, dua dari beberapa gunung suci yang ada (Media Hindu, (Edisi 159, Mei 2017, hal. 1).

Mirip dengan penggambaran di atas, melalui risetnya yang panjang di Bali, Stuart-Fox (2010) menyatakan, mitos tentang asal usul Gunung Agung sering dikaitkan dengan Hinduisasi yang menghubungkan bagaimana gunung tersebut dibawa dari India ke Pulau Jawa dan Bali. Puncak gunung dianggap sebagai kawasan suci dan merupakan tempat berbersemayam para penjaga 
kehidupan, bumi, dan roh para leluhur yang telah menganugrahkan kemakmuran bagi umat manusia, atau mengambil kembali dengan kemurkaannya membawa kematian dan kehancuran bagi dunia.

Gunung Agung bukan sekadar hal-ihwal pendakian yang menyediakan keindahan, eksotisme, dan kepuasaan manusia menaklukkan puncaknya sambil menikmati sunrise-nya. Daya tarik lahiriah seperti itu lazim dan jamak ada di banyak pengalaman mendaki gunung-gunung yang lain. Gunung Agung bukan sembarang gunung karena begitu disakralkan di Bali. Di sekitarnya terdapat pura-pura penting yang sangat dihormati. Di lokasi pertengahan gunung yang disucikan ini terdapat Pura Pasar Agung dan di kakinya berdiri Pura Besakih, pura terbesar di Bali. Pura Pasar Agung pernah menjadi korban letusan Gunung Agung pada tahun 1963. Sejak sekitar 1980-an pura tersebut perlahan-lahan dibangun kembali sampai berdiri kembali seperti dapat disaksikan saat ini.

Sebelum Pura Besakih berdiri megah seperti ini, dahulu kawasan ini merupakan hutan belantara dan dihuni banyak binatang buas. Saat itu, belum terdapat Selat Bali yang kini dikenal dengan Segara Rupek. Daratan Bali dan Jawa dahulu menyatu, artinya belum dipisahkan oleh laut (seperti sekarang). Daratan ini, yakni Bali dan Jawa, ketika masih menyatu bernama Pulau Dawa. Nama ini kemungkinan diberikan karena pulau ini tergolong panjang. Dalam Bahasa Bali, dawa memang berarti panjang (Tim Redaksi Bali Post, 2010: 5-6).

Pura Besakih dan Gunung Agung adalah paduan culture-nature yang sangat rancak. Gunung Agung adalah nature (alam) sedangkan Pura Besakih adalah sebentuk produk kebudayaan (culture). Semua aktivitas kependakian Gunung Agung dan semua prosesi keagamaan Pura Besakih pada akhirnya adalah culture. Justru kegiatan culture melalui pendakian Gunung Agung merupakan upaya back-to-nature (kembali ke alam) sembari mengagumi sang gunung (alam). Belakangan, ketika Bali dilanda industrialisasi pariwisata yang semakin intens, khususnya sejak dasawarsa 1990an, muncul interpretasi baru di mana gunung diposisikan sebagai daya tarik wisata. Gunung pun menjadi komoditas baru programprogram wisata penyelenggara perjalanan wisata. Akibatnya, Gunung Agung yang begitu disakralkan di Bali pun mengalami 
komoditisasi, komodifikasi, turistifikasi, atau apa pun istilahnya, lebih-lebih karena gunung ini berada di daerah tujuan wisata provinsial yang aktivitas pariwisatanya bahkan menjadi semacam ideologi.

Karena Gunung Agung bukan gunung biasa melainkan gunung yang dianggap sakral oleh masyarakat Bali tempat melinggih (bersemayam) Ida Bathara (Tuhan yang Mahaesa) di mana di sekitarnya terdapat pura-pura, maka dalam bahasa filosofisnya, mendaki Gunung Agung adalah mengalami spiritualitas. Menikmatinya adalah mencari kedamaian alam ciptaan Sang Pencipta. Ada aura spiritualitas yang sulit digambarkan dengan kata-kata saat mendaki. Tidak hanya pemandu pendakian, banyak wisatawan pendaki mengatakan demikian meskipun mereka bukan orang Bali dan tidak beragama Hindu. Getar-getar unik kespiritualan seperti itu hanyalah milik mereka yang pernah mendakinya, terutama yang berangkat dengan hati yang suci dan tulus ikhlas. Hal-hal seperti inilah yang menjadi nilai dan makna lebih mendaki Gunung Agung.

Di luar penggambaran di atas, perlu dicatat bahwa, sebagai gunung berapi yang menjadi bagian dari Cincin Api Pasifik (Pacific Ring of Fire), Gunung Agung juga memiliki potensi kebahayaan yang luar biasa terkait dengan kemungkinan letusannya seperti situasi yang terjadi pada bulan-bulan belakangan ini. Namun justru karena tantangan kebahayaan itulah ia semakin memiliki daya tarik untuk dinikmati, khususnya bagi para wisatawan petualang. Tidak mengherankan, ada saja wisatawan pendaki yang berusaha menerobos larangan pendakian yang diberlakukan saat ini demi kenikmatan menaklukannya sebagaimana yang diberitakan korankoran dan media sosial.

\section{Kepeloporan kewirausahaan memandu pendakian Gunung Agung}

Gunung Agung terletak di wilayah administratif Desa Sebudi di utara Desa Selat. Karena Desa Selat merupakan ibukota Kecamatan Selat, dan terutama orang-orangnya lebih cepat menangkap peluang bisnis, maka kewirausahaan memandu pendakian justru tumbuh dan berkembang di Desa Selat. Meskipun demikian, pendakian melalui Desa Selat tersebut hampir selalu berhubungan dengan 
pihak-pihak tertentu di Desa Sebudi karena desa ini merupakan rute menuju gunung tersebut di samping Pura Pasar Agung berada di desa ini. Antara Desa Selat dan Desa Sebudi terdapat Desa Amerta Buana yang menjadi batas utara wilayah administratif Desa Selat. Batas timur Desa Selat adalah Desa Duda; batas baratnya Desa Peringsari; dan batas selatannya Desa Sinduwati di Kecamatan Sidemen.

Desa Selat yang luasnya sekitar $80 \mathrm{~km} 2$ dan berpenduduk 34.760 jiwa dan terdiri atas delapan desa (berada sekitar $20 \mathrm{~km}$ dari pusat ibukota kabupaten (Amlapura) dan sekitar $50 \mathrm{~km}$ dari Kota Denpasar (ibukota Provinsi Bali). Desa Selat sendiri terletak di bagian selatan Gunung Agung, sehingga jalur pendakian ke Gunung Agung melalui desa ini disebut Jalur Selatan di mana pendakian melalui jalur ini biasanya menempuh waktu tiga sampai empat jam. Waktu tempuh ini tergantung situasi dan kondisi, kemampuan wisatawan pendaki, dan puncak mana yang dituju. Kebanyakan pendakian ke Gunung Agung dilakukan dari Jalur Selatan. Jalur lainnya adalah Jalur Barat di Besakih, Kecamatan Rendang dan Jalur Timur di Desa Budakeling. Satu Jalur Timur lainnya, yakni di Desa Juntal, Kecamatan Kubu, tergolong jalur yang dilarang karena berbahaya dan sangat berisiko.

Selat merupakan desa yang secara geografis tergolong subur terutama karena sebagian wilayahnya diterpa lahar saat Gunung Agung meletus pada tahun 1963. Tidak mengherankan, sebagian besar penduduknya adalah petani dan pedagang yang menjual hasil pertanian (hasil bumi) dan komoditas-komoditas lainnya di sebuah pasar relatif luas di tengah-tengah desa yang pasarannya berlangsung setiap hari. Termasuk di dalamnya adalah petani dalam arti luas, seperti pengolah pasir dan batu dari hasil letusan lima dasawarsa tersebut.

Di balik keberadaannya sebagai wilayah pertanian dari bekas letusan gunung api paling fenomenal di Bali, desa ini justru belakangan dikenal menghasilkan sejumlah wirausahawan berupa pemandu pendakian Gunung Agung. Ini menandakan kemampuan sejumlah tertentu anggota masyarakat setempat dalam menanggapi besarnya minat pasar pariwisata Bali di mana, dalam konteks teoretisasi Bourdieu (1990; lihat juga Takwin, 2009), mereka telah melakukan praktik, yakni sebagai subjek-subjek yang 
aktif menciptakan kebudayaannya sendiri. Sudah cukup banyak wisatawan yang menjajal Gunung Agung dengan diantar para pemandu dari desa ini.

Kewirausahaan wisata mendaki Gunung Agung di Desa Selat bermula pada dasawarsa 1990-an ketika sejumlah penduduk setempat berinisiatif memberikan layanan pendakian kepada para peminat atau pendaki atau siapa saja yang berniat mendaki Gunung Agung. Ketika ternyata pendakian-pendakian awal pada dasawarsa tersebut mulai membuat orang-orang semakin tertarik melakukannya, sejumlah papan nama kecil-kecil bertuliskan "volcano trekking" dan variannya menghiasi sejumlah ruas pinggir desa yang menandakan pemasangnya menyediakan layanan pemanduan pendakian.

Ada empat tokoh pemandu yang layak disebut memulai prakarsa dan sekaligus memelopori kewirausahaan wisata mendaki Gunung Agung di Desa Selat. Mereka adalah I Wayan Sukra, I Nengah Kari, Gung Bawa, dan I Wayan Tegteg. Sukra dan Kari yang mengawali pekerjaan guiding-nya sejak awal 1990-an benar-benar lahir, besar, dan tinggal sampai kini di desa setempat. Gung Bawa lahir dan besar di Desa Selat tetapi sejak 2006 bolakbalik Desa Selat-Denpasar karena istrinya pegawai bank di kota ini dan kedua anaknya masih kecil. Di Denpasar ia tinggal di wilayah Panjer tetapi selalu menyempatkan pulang kampung di hari-hari libur terutama saat ada order pendakian sekalian bersembahyang di pamerajan (sanggah/pura keluarga) di rumahnya di Desa Selat. Tegteg bukan asli orang Desa Selat tetapi hingga saat ini menjadi penduduk tetap desa ini dan telah lama mengantongi KTP (kartu tanda penduduk) setempat. Ia dahulu adalah guru sekolah dasar dan bertugas di tempat-tempat sekitar desa ini sejak 1977 dan akhirnya memutuskan untuk menambah penghasilan dengan menjadi guide pendakian sejak ia menjelang pensiun.

I Wayan Sukra (46 tahun), lulusan Diploma-1 Kepariwisataan, dari Dusun/Banjar Selat Kelod pada awalnya adalah seorang pedagang di desanya. Ketika wisata mendaki Gunung Agung mulai tumbuh di desanya, di sela-sela waktu berdagangnya, bila ada tawaran job, Sukra akan mengutamakan memandu pendakian. Bagaimana pun usaha mengantar tamu mendaki secara penghasilan jauh lebih menguntungkan daripada kegiatan dagang apalagi ia 
mampu berbahasa Inggris meskipun tidak lancar benar. Setidaknya ia memeroleh palingsedikitRp.400.000daripengantarannya.Jumlah itu berarti "banyak" untuk orang-orang desa seperti dirinya. Itulah sebabnya, ia siap meninggalkan pekerjaan berdagangnya untuk sementara waktu apabila ada wisatawan pendaki memesannya. Pekerjaan berdagang tetap ia lakukan sampai saat ini karena bagaimana pun pekerjaan mengantar wisatawan mendaki bersifat musiman. Tidak semua hari bisa dilakukan pendakian karena semuanya tergantung pada alam (kondisi cuaca) di samping pendakian tersebut tidak boleh dilakukan pada tiga hari sebelum hingga empat hari sesudah berlangsungnya upacara keagamaan (pujawali) di Pura Pasar Agung pada setiap Budha Wage Ukir dan tiga hari sebelum hingga sebelas hari sesudah hari Purnama ke-5 (kelima) dan ke-10 (kedasa). Sesuai aturan-aturan umum setempat yang berlaku, bila ada rangkaian upacara seperti itu, tidak ada boleh ada pendakian agar tempat tersebut tidak cemer/leteh (kotor). Guide lokal seperti Sukra sangat memahami dan percaya hal itu.

Sama dengan Sukra, I Nengah Kari (45 tahun) dari Dusun/ Banjar Selat Kaja adalah lulusan Diploma 1 Kepariwisataan. Ia sosok pemimpin di desanya karena secara formal ia kepala dusun di Dusun (Banjar) Kaja. Sebagai orang desa yang membutuhkan penghasilan tambahan, ia pun berprofesi sebagai guide pendakian di luar kesibukannya sebagai kepala dusun. Pekerjaannya menjadi guide tidak terlalu mengganggu waktunya sebagai kepala dusun. Apalagi pendakian selalu dimulai sore atau malam hari dan besok paginya (sebelum siang) sudah balik (turun). Sebagaimana Sukra, ia menggunakan media sosial, seperti Facebook, dan mampu berkomunikasi dengan wisatawan pendaki mancanegara dalam bahasa Inggris meskipun tidak terlalu fasih.

Setelah Sukra dan Kari, orang lokal lainnya adalah Gung Bawa yang memiliki nama lengkap Anak Agung Ngurah Wibawa (43 tahun). Gung Bawa yang lulusan Diploma 1 Food and Beverages (Makanan dan Minuman) di perguruan tinggi kepariwisataan bernama Dhyana Pura, Dalung, Badung, tergolong berpengalaman dalam melayani pendakian Gunung Agung dan, selama karirnya itu, telah ratusan kali melakukan kegiatan tersebut secara aman dan sudah memahami betul tingkat kesulitan yang ada. Mendengar pengakuan mengenai pengalaman dan kemampuan 
serta melihat secara umum penampilan calon pendaki, ia dengan arif bisa menyarankan si calon pendaki tentang puncak mana yang sebaiknya dicapai dan rute mana yang seharusnya ditempuh.

Gung Bawa meskipun tidak sesenior Sukra dan Kari tetapi pandangan ketiganya hampir sama, yakni sama-sama mengakui keanehan dan keunikan Gunung Agung secara spiritual-relijius. Tentu tujuan awal ketiganya sebagai guide pendakian adalah mencari penghasilan. Semakin sering mengantar tamu melakukan pendakian, semakin ia rasakan dan alami kebesaran Tuhan atas gunung ini. Ia pun sangat patuh terhadap semua ketentuan tertulis maupun tak tertulis (pantangan dan tabu) dalam hal pendakian. Misalnya, pendaki tidak boleh bicara sembarangan dan tidak diizinkan membawa makanan dari bahan daging sapi karena sapi adalah hewan yang dianggap suci. Di samping itu, apabila dalam perjalanan ditemukan mata air, yang merupakan air suci, harus dilakukan persembahyangan terlebih dahulu atau setidaknya minta tolong kepada guide untuk memanfaatkannya.

Sebagaimana halnya Sukra dan Kari, Gung Bawa melayani wisatawan pendaki dengan kejujuran cultural capital (modal budaya) yang dimilikinya, yakni pengetahuan tentang kegunungagungan yang ia dengar, ketahui, rasakan, dan alami yang penuh dengan cerita kemahakuasaan Tuhan yang ia sendiri sangat yakini kebenarannya. Pesan Gung Bawa sederhana bahwa Gunung Agung bukan tentang sekadar nikmatnya mendaki, puasnya menaklukkan puncak gunung, atau indahnya pemandangan sunrise (matahari terbit) terlihat dari puncak gunung tetapi tentang kebesaran Tuhan Sang Pencipta Gunung Agung dan tanda-tanda spiritualitasreligiusitas saat pendakian, dan berbagai hal yang sulit dipercaya menurut akal sehat.

Gung Bawabahkan sering menangani wisatawan pendaki yang sudah berkali-kali mendaki gunung ini. Sebagai contoh, Ken dari Inggris sudah 10 kali melakukannya sementara Iway dari Jepang sudah empat kali. Tidak mengherankan, ia mendapat pujian dari berbagai penjuru dunia. Untuk mendukung profesionalismenya di bidang pengantaran pendakian, ia juga memiliki media sosial facebook dan blogspot, yaitu gb-trekking.blogspot.com (diunduh 19 Juni 2017). Ia pun dikenal dengan tag-nya: much more than just trekking (jauh lebih dari sekadar trekking). 


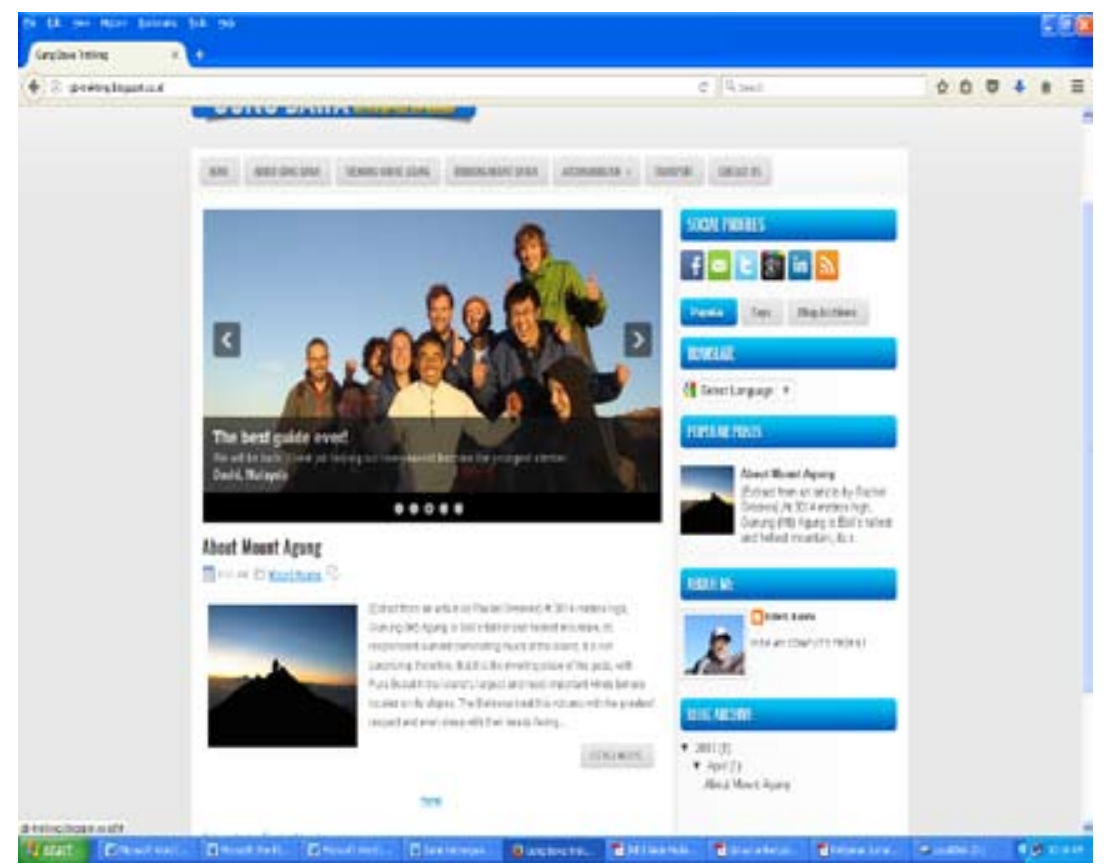

Foto 1. Salah satu strategi kewirausahaan Anak Agung Ngurah Wibawa (Gung Bawa) menggaet pasar wisata pendakian lewat teknologi informasi (internet) (Dokumentasi: Anak Agung Ngurah Wibawa/ Gung Bawa, 2017).

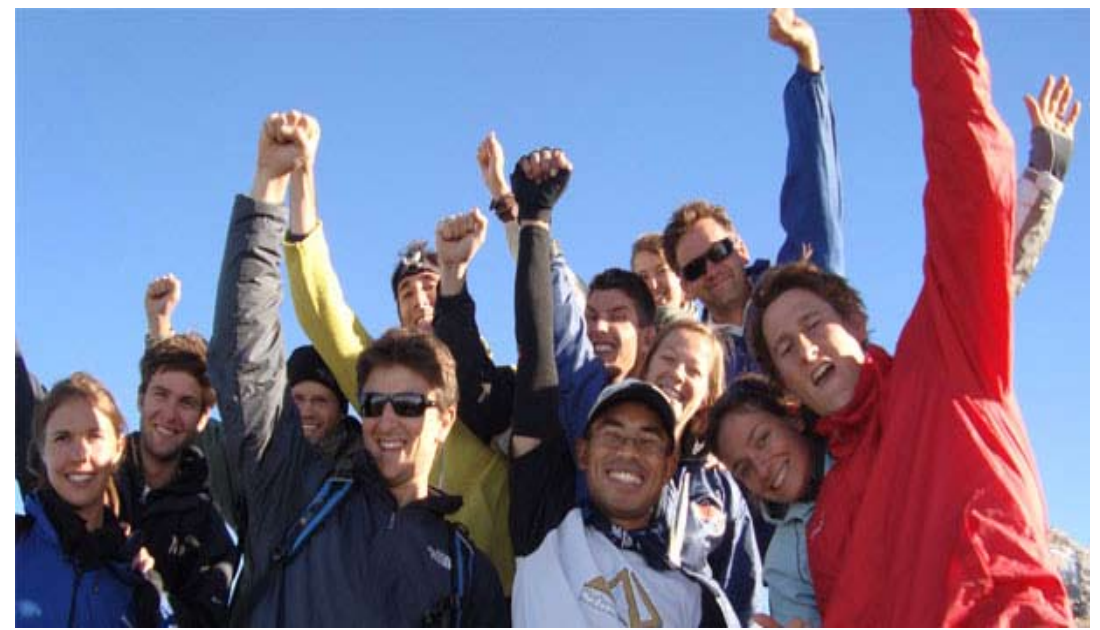

Foto 2. Ekspresi kebahagiaan rombongan wisatawan pendaki yang diantar Gung Bawa saat baru saja mencapai puncak Gunung Agung (Dokumentasi: Anak Agung Ngurah Wibawa/Gung Bawa, 2017). 
Sejak tahun 2000 muncul seorang pemandu lainnya bernama I Wayan Tegteg. Meskipunbukan orang aslidesa setempat, Tegtegsaat ini menunjukkan eksistensinya sebagai pemandu yang andal dan disuka. Umurnya tidak lagi muda karena sudah mencapai 63 tahun tetapi passion-nya mengantar wisatawan mendaki mengagumkan. Kini, lulusan SPG (Sekolah Pendidikan Guru) Negeri Klungkung ini berdomisili di Desa Selat dan senang tinggal di desa ini. Ia lahir di Desa Dawan pada tahun 1954. Ia memiliki istri dan dua anak. Anak pertamanya bekerja sebagai PNS di Kota Denpasar sedangkan adiknya bekerja di Desa Manggis, Karangasem. Tegteg menempati sebidang tanah yang lokasinya cukup strategis di Desa Selat, dekat Puskesmas Selat, di mana ia mendirikan sebuah warung makan cukup ramai pembeli. Di sebelah warung di pinggir jalan tepat di sisi Tukad (Sungai) Kalangidi ia mengelola kolam ikan yang produknya ia jual langsung dan ada juga dimasak dan dijual di warung yang ditunggui istrinya, seperti ikan nila. Pascajadi guru, ia lebih berkonsentrasi menjadi pengantar pendakian karena pekerjaan mengurus kolam dan ikan-ikannya tidak terlalu sulit dan bisa digantikan istrinya.

Memiliki niat besar menjadi pemandu pendakian, pada awalnya Tegteg berupaya menyewa orang untuk mengetahui rute pendakian. Saat itu ia membayar orang tersebut Rp. 50.000. Saat ini ia bisa memeroleh setidaknya Rp. 500.000 untuk sekali mengantar dengan paling banyak dua atau tiga orang wisatawan pendaki. Profil, kegiatan, dan pencapaiannya terpampang dengan jelas di media sosial yang digunakannya, seperti Facebook, Instagram, dan blog. Yang menarik dari Tegteg adalah pandangannya dalam berkewirausahaan terkait Gunung Agung. Baginya melayani wisatawan pendaki ke gunung ini adalah mencari penghidupan (make a living) selain, yang tidak kalah pentingnya adalah, bergaul dan berkomunikasi dengan orang-orang baru dari seluruh dunia sekaligus berolah tubuh dan pikiran agar bisa refreshed. Sebagai pensiunan guru SD pendapatannya per bulan dirasakan tidak terlalu mensejahterakan meskipun kedua anaknya sudah menikah, mandiri, dan tidak tinggal bersamanya lagi. Karenanya ia mencoba mengadu peruntungan di pendakian. 

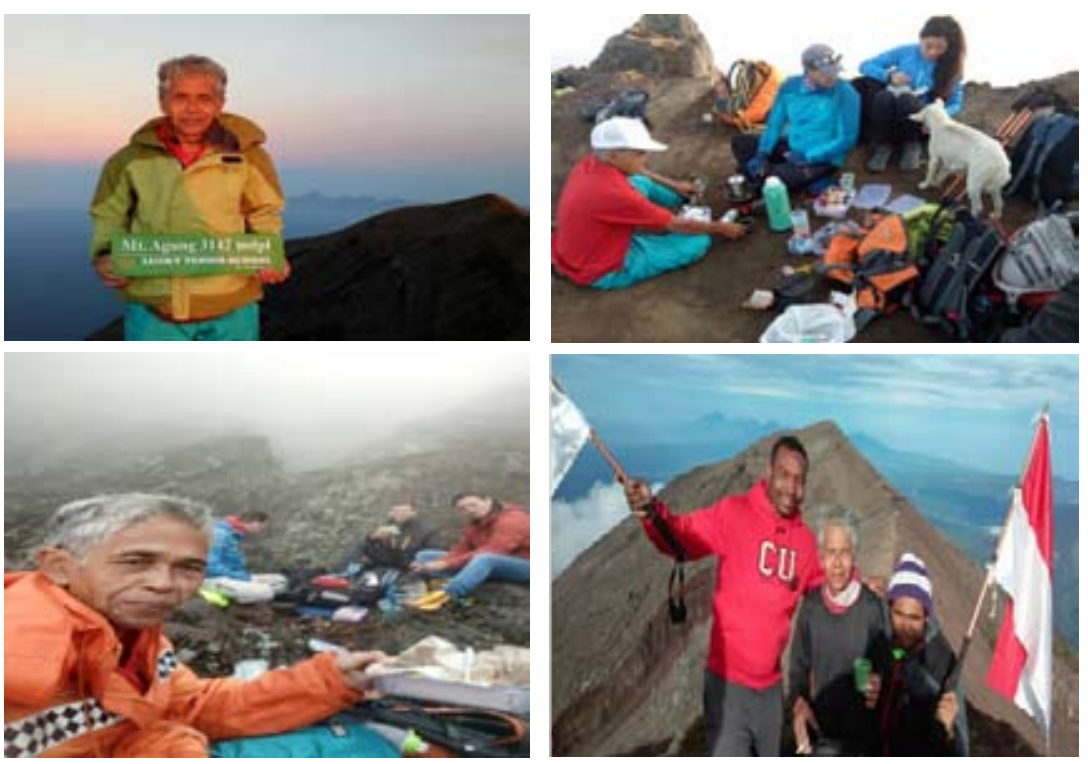

Foto 3. Sosok guide pendakian Gunung Agung I Wayan Tegteg dan aktivitas pelayanan pendakian Gunung Agung yang dilakukannya dalam beberapa pendakian (Dokumentasi: I Wayan Tegteg, 2017).

Tegteg tergolong moderat apalagi ia dahulu guru mata pelajaran IPA dan matematika. Secara jujur ia mengakui dirinya mempraktikkan spiritualitas-religiusitas dengan caranya sendiri. Saat mengantar pendakian ke Gunung Agung, ia tidak terlalu sering melakukan bentuk-bentuk formal praktik spiritualitas. Ini tidak berarti bahwa ia tidak meyakini spiritualitas yang dimiliki aura gunung ini melainkan ia lebih banyak melakukannya dengan cara yang lebih sederhana, yakni cukup dengan menghaturkan canang (sesajen kecil) sambil tidak lupa melantunkan doa-doa yang tulus dari dalam hati yang substansinya adalah memohon keselamatan dan perlindungan untuk diri dan yang diantarnya selama memandu demi taraf kehidupannya yang lebih baik.

Semua daya tarik Gunung Agung yang ada membuat kewirausahaan memandu pendakian di Desa Selat tumbuh seperti ini sehingga sangat disyukuri seluruh pelakunya (Mudana, et al, 2017). Sebagai pemandu wisata gunung, di samping melayani sebaik-baiknya serta menjaga keselamatan dan kenyamanan wisatawan pendaki, Sukra, Kari, Gung Bawa, dan Tegteg bersepakat untuk menjaga kelestarian Gunung Agung dan sangat 
tidak setuju dengan tindak pengerusakan terhadap apa pun yang ada di gunung. Mereka juga berkomitmen menjaga kesucian dan kesakralan gunung ini. Mereka telah membuktikan bahwa gunung ini telah memberikan mereka peluang menambah penghasilan lewat mengantar pendakian.

\section{Simpulan}

Kegiatan sejumlah anggota masyarakat di Desa Selat sebagai pemandu pendakian menunjukkan bahwa mendaki gunung, dalam hal ini Gunung Agung, layak dikembangkan sebagai produk pariwisata berbasis masyarakat dalam pengertian yang sebenarnya, atau lebih tepat "pariwisata berbasis masyarakat berbasis pegunungan (mountain-based community-based tourism)" di mana jenis yang satu ini terkait dengan pariwisata alam/nature tourism, pariwisata berkelanjutan/sustainable tourism (pariwisata hijau/green tourism), pariwisata alternatif/alternative tourism, dan pariwisata pedesaan (rural tourism). Kegiatan kewirausahaan masyarakat Desa Selat ini dapat dikatakan pelopor dan terbesar di Bali mengingat Gunung Agung adalah gunung tertinggi. Jalur Desa Selat juga merupakan jalur teramai dibandingkan seluruh jalur lain ke gunung ini.

Terkait hal di atas, konsep tradisi-keagamaan di Bali berupa ritual nyegara-gunung, dapat dipinjam dan ditransformasikan ke kosakata kepariwisataan, di mana sea-sand-sun (segara/laut) yang sudah sedemikian klasik sebagai produk pariwisata populer diseimbangkan dan/atau disempurnakan olehpendakiankegunung (/gunung), yakni trekking/climbing ke wilayah-wilayah tinggi. Lebih dari itu, dalam pelayanan pendakian, unsur masyarakat sebagai pelaku pariwisata, yakni menjadi pemandu wisatawan pendaki, tampak nyata dibandingkan pariwisata massa sea-sand-sun yang cenderung kapitalistik atau lebih banyak memberikan keuntungan bagi pemodal-pemodal besar. Kisah-kisah kewirausahaan Sukra, Kari, Gung Bawa, dan Tegteg dalam studi ini menunjukan fenomena tersebut.

Kewirausahaan, sebagaimana dinyatakan oleh Hisrich dan Peters (1995) serta Siagian (1995), termasuk di dalamnya aktivitas wisata memandu pendakian Gunung Agung di Desa Selat, tidak terlepas dari diskursus kemasyarakatan, dikaitkan dengan keinginan untuk memperbaiki kehidupan ke tingkat dan kualitas 
yang lebih baik. Kewirausahaan memandu wisata mendaki Gunung Agung sejalan dengan prinsip-prinsip pentingnya entitas masyarakat (sebagai salah satu stakeholder) dalam pengembangan pariwisata berbasis masyarakat seperti dikemukakan oleh Dengnoy (2003). Lebih-lebih Selat adalah sebuah desa yang masyarakatnya berkepantasan memanfaatkan daya tarik Gunung Agung untuk perbaikan hidup karena merupakan salah satu desa terdekat gunung tersebut.

Tokoh-tokoh guide Gunung Agung dalam studi ini telah dengan sadar mencoba membuat apa yang disebut Bourdieu (1990) sebagai habitus (kebiasaan). Hal ini tentu saja kebiasaan yang positif dan produktif, dari peluang bisnis yang disebut Bourdieu (1990) sebagai ranah (field) beserta modal (capital) budaya yang dimiliki, dalam hal ini pengetahuan tentang berbagai rahasia alam Gunung Agung beserta aspek-aspek mitologis dan spiritualitas terkait. Apalagi, di kalangan pencinta pendakian Gunung Agung ada semacam adagium bahwa kalau mendakinya, suka atau tidak suka, harus diantar guide setempat karena sebagai orang lokal si guide memahami betul medan, situasi dan kondisi serta terutama hal-hal lain yang sifatnya spiritual-religius.

Melihat semua itu, para stakeholder, terutama pemerintah dan swasta (industri pariwisata), sebaiknya tidak berpangku tangan. Kepeloporan kewirausahaan memandu wisata pendakian Gunung Agung di Desa Selat harus ditindaklanjuti, dikembangkan, ditularkan kepada anggota masyarakat lainnya, dan dibuat lebih mendatangkan keuntungan bagi para pelakunya. Banyak hal yang pihak lain seharusnya bisa lakukan, misalnya pengorganisiasian produk secara lebih profesional, pemasaran (marketing), networking, dan pembuatan situs (website) yang terintegrasi. Bila pengelolaan kewirausahaan ini mau dimaksimalkan, Pemerintah Kabupaten Karangasem bisa mendayagunakan potensi-potensi kepariwisataan lainnya di sekitar Gunung Agung dan Desa Selat, seperti usaha penginapan di wilayah Tebola, Desa Sidemen, arung jeram (rafting) di Desa Rendang, tari Sanghyang di Dusun Jangu, Desa Duda, agrowisata Salak di sekitar Kalangangnyar-Telaga-Sibetan, atau pasar tradisional di Desa Selat dan Dusun Pesangkan serta di titiktitik pariwisata yang lebih luas. Keterlibatan stakeholder dalam bentuk-bentuk pariwisata berbasis masyarakat sudah diingatkan oleh para pemerhati pariwisata, tidak saja oleh Dengnoy (2003) 
tetapi juga Nugroho dan Aliyah (2013). Kerjasama politik-ekonomibudaya antara pemerintah, swasta, dan masyarakat bahkan menjadi sebuah keharusan menurut konsepsi Perlas (2000) meskipun apa yang terjadi di Desa Selat merupakan sebentuk kewirausahaan pedesaan di mana Gunung Agung dan Selat sendiri secara geografis relatif jauh dari pusat-pusat kepariwisataan Bali.

Dalam cakupan yang lebih luas, yakni provinsial, harus disadari bahwa Bali tidak hanya Kuta, Sanur, Nusa Dua, atau Lovina tetapi juga meliputi seluruh wilayah yang ada, termasuk pelosok-pelosok dan daerah-daerah pegunungan. Apalagi menjadi guide pendakian penuh dengan risiko, termasuk risiko fisik dan jiwa (nyawa) dan bahkan mereka pada dasarnya tidak seberuntung guide konvensional yang job-nya datang secara regular. Saat ini, bahkan mereka tidak bisa melakukan job-nya ketika pemerintah melarang pendakian sejak pertengahan September 2017 dengan adanya tanda-tanda Gunung Agung akan meletus. Selain mereka tidak dijamin (oleh pemerintah), maksudnya tidak memiliki asuransi, pekerjaan memandu wisatawan mendaki gunung, khususnya Gunung Agung, hanya berlangsung pada bulan-bulan tertentu saat kondisi alam mendukung. Untuk mereka, sebagaimana disarankan oleh Tolkach dan King (2015), sungguh-sungguh diperlukan keberpihakan nyata para pemangku kepentingan, khususnya kekuasaan (pemerintah).

\section{DAFTAR PUSTAKA}

Amerta, I Made Suniastha dan I Gede Mudana. 2017. "The Meanings of the Development of Alternative Tourism at Jasri Village, Subagan Sub-District, Karangasem", E-Journal of Cultural Studies, Vol.10, No. 1, February edition (https://ojs.unud.ac.id/ index.php/ecs/article/view/32124, diunduh 25 Agustus 2017).

Bourdieu, Pierre. 1990. The Logic of Practice. Cambridge: Polity Press.

Hisrich, Robert D. and Michael E. Peters. 1995. Entrepreneurship (4th Edition). Boston: Mass Irwin/McGraw Hill.

Miles, Matthew B. dan Michael A. Huberman. 1992. Analisis Data Kualitatif (terjemahan). Jakarta: UII Press.

Media Hindu. 2017. "Gunung Suci dalam Agama-agama", Media Hindu, Edisi 159, Mei 2017, hal. 1. 
Mudana, I Gede, I Ketut Sutama, dan Cokorda Istri Sri Widhari. 2017. "Entrepreneural Figure of Mount Agung Trekking Guides", E-Journal of Cultural Studies, Vol. 10, No. 3, August edition (https://ojs.unud.ac.id/index.php/ecs/article/view/33150, diunduh 08 Oktober 2017).

Nugroho, Purwanto Setyo dan Istijabatul Aliyah. 2013. "Pengelolaan Kawasan Wisata Berbasis Masyarakat sebagai Upaya Penguatan Ekonomi Lokal dan Pelestarian Sumber Daya Alam", Jurnal Cakra Wisata, Surakarta, Vol. 13, Jilid 1.

Perlas, Nicanor. 2000. Shapping Globalization: Civil Society, Cultural Power and Threefolding. New York: CADI and Global Network for Social Threefolding.

Putra, I Nyoman Darma (ed.). 2015. Pariwisata Berbasis Masyarakat Model Bali. Denpasar: Buku Arti bekerja sama dengan Prodi Magister Kajian Pariwisata Unud.

Sanjaya, I Wayan Kiki dan I Gede Mudana. 2017. “Compassionate Capitalism in Hotel Industry in Ubud, Bali", E-Journal of Cultural Studies, Vol. 10, No. 2, May edition (https://ojs.unud. ac.id/index.php/ecs/article/view/32131, diunduh 25 Agustus 2017).

Siagian, Salim. 1995. "Kewirausahaan dengan Semangat 17.8.45", Puslatkop, Jakarta.

Stuart-Fox, David J. 2010. Pura Besakih: Pura, Agama, dan Masyarakat Bali. Jakarta: Pustaka Larasan.

Sudikan, Setya Yuwana. 2001. Metode Penelitian Kebudayaan. Surabaya: Unesa Unipress dan Citra Wacana.

Takwin, Bagus. 2009. Akar-akar Ideologi: Kajian Konsep Ideologi dari Plato hingga Bourdieu. Yogyakarta: Jalasutra.

Tim Redaksi Bali Post. 2010. Mengenal Pura, Sad Kahyangan dan Kahyangan Jagat, cetakan ketiga. Denpasar: PT Offset BP Denpasar/Pustaka Bali Post.

Tolkach, Denis and Brian King. 2015. "Strengthening CommunityBased Tourism in a New Resource-based Island Nation: Why and How?" Tourism Management (Journal), Vol. 48, June, hal. 386-398.

Zhao, Weibing and J.R. Brant Ritchie. 2007. "Tourism Poverty Alleviation: An Integrative Research Framework", Current Issues in Tourism (Journal), Vol. 10, Issue 2-3, hal. 119-143. 